\title{
高純度マグネシア焼結体の機械的性質に及ぼす粒子径の影響
}

\author{
西田明生・島村常夫・神徳泰彦 \\ (宇部興産 (株) 研究開発本部, 755 山口県宇部市大字小串 1978-5)
}

\section{Effect of Grain Size on Mechanical Properties of High-Purity Polycrystalline Magnesia}

\author{
Akio NISHIDA, Tuneo SHIMAMURA and Yasuhiko KOHTOKU \\ (Corporate Research and Development, UBE Industries Ltd., 1978-5, Kogushi, Ube-shi, Yamaguchi
}

755

\begin{abstract}
High-purity polycrystalline magnesia with different microstructures were prepared, and the effects of grain size on their bending strength and thermal shock damage resistance were investigated. The bending strength $\left(\sigma_{B}\right)$ increased with decreasing grain size $(D: \mu m)$, and expressed by following equation. $\sigma_{B}=403 D^{-0.26}(\mathrm{MPa})$. On the other hand, the thermal shock damage resistance increased linearly with increasing grain size, which was explained by the damage resistance parameter, $R^{\prime \prime \prime}=E / \sigma_{T}{ }^{2}(1-\nu)$, where $E$ is Young's modulus, $\nu$ is Poisson's ratio and $\sigma_{T}$ is tensile strength. $E$ and $\nu$ are unchanged and $\sigma_{T}\left(\sigma_{B} \times 0.6\right)$ decreased with increasing grain size, so $R^{\prime \prime \prime}$ increased with increasing grain size. Consequently, thermal shock damage resistance increased with increasing grain size.
\end{abstract}

[Received October 20, 1989; Accepted December 11, 1989]

Key-words : Magnesia, Mechanical properties, Strength, Thermal shock resistance, Microstructure, Grain size

\section{1. 緒言}

高純度マグネシア焼結体は酸化鉛，アルカリ金属に対 する高温での耐食性に優れているため, PZT 焼成用セッ ター， $\beta$-アルミナ焼成用るつぼなどに使用される。しか し, マグネシアは強度が低く, 耐熱衝撃性に劣るので, これを改善することが期待されている，既に，ウイス カー, ジルコニアなどによるマグネシアの強化が知られ ているが'11,2)，この方法ではマグネシアの耐食性が低下 する。したがって, 強度や耐熱衝撃性は焼結体の微構造 の制御により改善することが望ましい.一般に,セラミッ クスの機械的性質は粒子径, 気孔率, 内部久陥なよ゙の微 構造に影響され，マグネシア焼結体の強度についてもこ れまで多くの研究がなされてきた ${ }^{3), 4)}$.しかし，耐熱衝 撃性については十分な研究がなされていない。

本研究では，気相法により製造した高純度マグネシア 粉末を原料として，作製した高純度マグネシア焼結体の 曲げ強度と熱衝撃損傷抵抗に及ぼす彺構造の影響を調べ たので，その結果を報告する．

\section{2. 実験方法}

粒子径の異なる 3 種類のマグネシア粉末 $(0.054$, $0.126,0.199 \mu \mathrm{m})$ を実験に用いた。これらの粉末はマ
グネシウムを加熱し発生したマグネシウム蒸気を気相酸 化して製造したものであり，純度は $99.9 \%$ 以上である.

この粉末をエタノール溶媒中で 5 時間ボールミルした 後に乾燥して得られた塊状物をめのう乳鉢で解砕して造

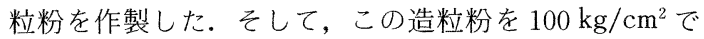
一軸加圧成形後, $1.5 \mathrm{t} / \mathrm{cm}^{2}$ で静水圧加圧を行い成形体 を作製した。次に，この成形体を電気炬に入れ大気中， $5^{\circ} \mathrm{C} / \mathrm{min}$ で $1650^{\circ} \mathrm{C}$ まで昇温し, 所定の時間 $(0,1,4)$ 保持した後 $5^{\circ} \mathrm{C} / \mathrm{min}$ で降温して焼結体を得た。

得られた焼結体の密度はアルキメデス法により求め た. また，微構造は焼結体破断面を走査型電子顕微鏡 (SEM) により観察し, 焼結体の粒子径は SEM 写真 より Feret 径を測定して求めた。

焼結体の曲げ強度はJIS R 1601 に従い 3 点曲げ試験 を行い測定した。

熱衝撃損傷抵抗は曲げ強度の試験片を半分に切断した $3 \times 4 \times 20 \mathrm{~mm} の$ 棒状試験片を用いて急熱急冷繰り返し 法により次のようにして測定した。試料を $700^{\circ} \mathrm{C}$ に保 持した堅型環状電気炬に入れ，5分間保持した後に室温 流水中 $\left(25^{\circ} \mathrm{C}\right)$ に浸漬し 1 分後に, 再び, 試料を電気 炬に挿入するという熱サイクルを繰り返し，試料が破断 するまでの回数を測定した。 


\section{3. 実験結果及び考察}

原料及び焼結条件を変えて作製した焼結体の気孔率, 粒子径を表 1 に示す. 気相法マグネシア粉末の焼結性に ついては，既に報告したように，出発原料の粒子径に影 響される ${ }^{5)}$. 粒子径が小さいと粒成長しやすく，粒子径 が大きいと緻密化は遅いが粒成長はしにくい。この性質 を利用して焼結体の粒子径は $0.31 \mu \mathrm{m}$ から $48 \mu \mathrm{m}$ ま で, 焼結体の気孔率は $0.5 \%$ から $14 \%$ まで変化させる ことができた.

図 1 にマグネシア焼結体の粒子径と曲げ強度との関係 を示す. 粒子径 $1 \mu \mathrm{m}$ 以下の NO.4, 7, 8 の試料では気 孔率が大きいため, 粒子径と強度との相関はないが, 気 孔率 $2.1 \%$ 以下の試料において, 強度は粒子径が増大す るとともに徐々に低下した，また，NO. 9 の粒子径 1.2 $\mu \mathrm{m}$ の試料で曲げ強度は $324 \mathrm{MPa}$ になり常圧焼結のマ グネシア焼結体としては非常に高い値を示した。

Table 1. Properties of sintered bodies prepared from different powders and conditions.

\begin{tabular}{|c|c|c|c|c|}
\hline & Starting & Sintering & Sintered & Bodies \\
\hline No. & $\begin{array}{l}\text { Size } \\
(\mu \mathrm{m})\end{array}$ & $\begin{array}{c}1650^{\circ} \mathrm{C} \\
(\mathrm{hr})\end{array}$ & $\begin{array}{c}\text { Porosity } \\
(\%)\end{array}$ & $\begin{array}{c}\text { Grain Size } \\
\qquad(\mu \mathrm{m})\end{array}$ \\
\hline 1 & 0.05 & 0 & 2.0 & 26.2 \\
\hline 2 & 0.05 & 1 & 1.9 & 35.1 \\
\hline 3 & 0.05 & 4 & 1.7 & 48.0 \\
\hline 4 & 0.12 & 0 & 7.3 & 0.34 \\
\hline 5 & 0.12 & 1 & 0.6 & 4.0 \\
\hline 6 & 0.12 & 4 & 0.5 & 4.9 \\
\hline 7 & 0.19 & 0 & 14.0 & 0.31 \\
\hline 8 & 0.19 & 1 & 6.8 & 0.77 \\
\hline 9 & 0.19 & 4 & 2.1 & 1.2 \\
\hline
\end{tabular}

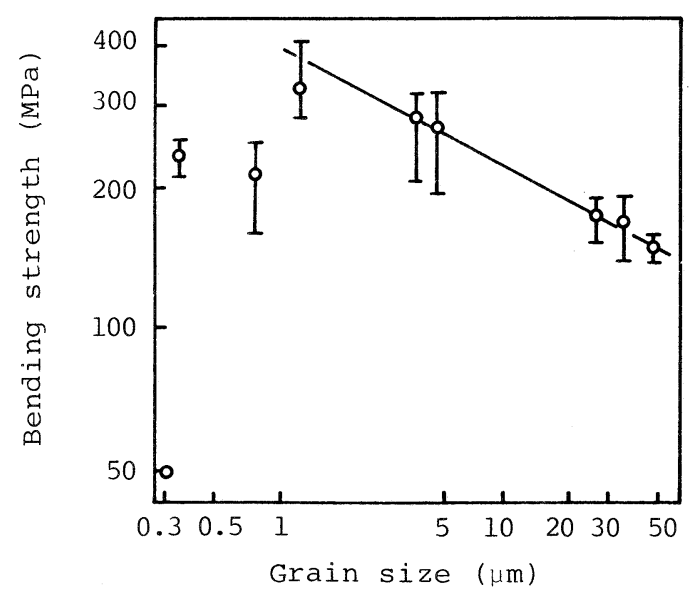

Fig. 1. Relation between grain size and bending strength.
このような粒子径と強度との関係については多くの研 究がおこなわれ, 次式が導き出されている6).

$$
\sigma_{\mathrm{B}}=K D^{-\alpha}
$$

ここで， $\sigma_{\mathrm{B}}$ は曲げ強度 $(\mathrm{MPa}), D$ は粒子径 $(\mu \mathrm{m}), K$, $\alpha$ は定数である. 本実験のデー夕からこれら定数を求め たところ， $K=403 \mathrm{MPa}, \alpha=0.26$ であった。

図 2 に粒子径亡熱衝撃損傷抵抗（破断までのサイクル 数）との関係を示す. 気孔率の大きいNO.4, 7,8の試 料は水中に投入したときに気孔に入った水の沸騰により 爆裂し, 1 回で破断した。一方, 気孔率の小さい他の試 料では熱衝撃損傷抵抗は粒子径の増大とともにほぼ直線 的に増加し, 熱衝撃損傷抵抗は粒子径に強く依存するこ とが認められた。

このように粒子径の増大とともに熱衝撃損傷抵抗が大 きくなるという関係は熱衝撃損傷抵抗係数から説明でき ると考えられる. 損傷抵抗係数は熱衝撃が与えられたと き，熱応力により発生したクラックがよ゙の程度進展する かを表す係数であり, 次の式が提案されている7 。

$$
\begin{aligned}
& R^{\prime \prime \prime}=E / \sigma_{\mathrm{T}}(1-\nu) \\
& R^{\prime \prime \prime \prime}=E \gamma / \sigma_{\mathrm{T}}{ }^{2}(1-\nu)
\end{aligned}
$$

ここで, $E$ はヤング率， $\gamma$ は破壊エネルギ一， $\sigma_{\mathrm{T}}$ は 引張強度，vはポアソン比である。（2）式は物性が類 似している材料間の熱衝撃損傷抵抗を比較する場合, $\gamma$ が共通と考えて (3) 式の $\gamma$ を省略したものである. マグネシアの破壊エネルギ一の粒子径依存性についての 研究 $^{81,9)}$ によれば，特に大きな依存性が認められないの で，（2）式の $R^{\prime \prime \prime}$ により熱衝撃損傷抵抗を比較した。 $R^{\prime \prime \prime}$ の算出に際し, 各値は次の值を用いた。 $\sigma_{\mathrm{T}}$ は試験片 の曲げ強度 $\left(\sigma_{\mathrm{B}}\right)$ の 0.6 倍とし, $E$ は試験片の気孔率 $(P)$ を $E=3.226 \times 10^{6} \mathrm{e}^{-4.74 \mathrm{P}}$ 式草) に代入し求め $(P$ は気孔 率), $\nu$ は $0.4^{11)}$ とした。

算出した結果を表 2 に示す。（2）式から分かるよう に $R^{\prime \prime \prime}$ は強度の低下とともに増える傾向にある. そして,

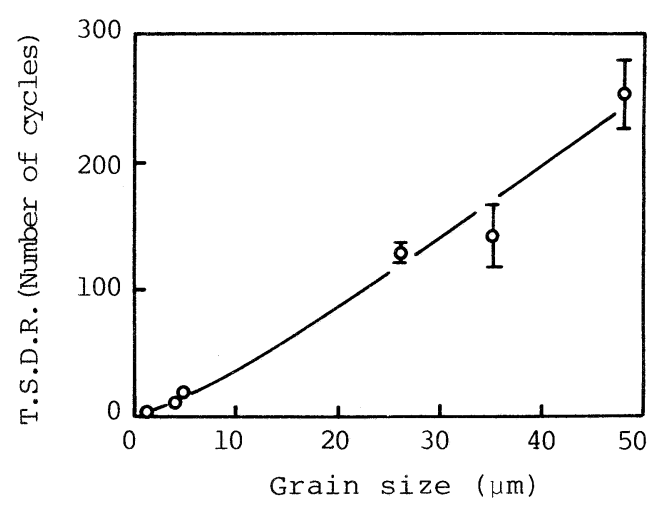

Fig. 2. Relation between grain size and thermal shock damage resistance (T.S.D.R.) that number of cycles to failure. 
これを基に作成した $R^{\prime \prime \prime}$ と熱衝撃損傷抵抗（破断するま でのサイクル数) との関係を図 3 に示す。ただし，気孔 率の大きい試料は気孔に入った水の沸騰により爆裂した ので，気孔率の小さい試料の值のみをプロットした。

熱衝撃損傷抵抗は $R^{\prime \prime \prime}$ が增大するとともに急激に大き くなり，熱衝撃損傷抵抗と $R^{\prime \prime \prime} と の$ 間には強い相関が認 められる. 先に述べたように曲げ強度と粒子径との間に は（1）式で示される関係があるので，（2）式は次の ように表される。

$$
R^{\prime \prime \prime}=E D^{2 \alpha} /(0.6 K)^{2}(1-\nu)
$$

Table 2. Calculated values of physical properties of spesimens.

\begin{tabular}{cccc}
\hline Nensile & $\begin{array}{c}\text { Young's } \\
\text { Strength } \\
\text { Modulus } \\
(\mathrm{GPa})\end{array}$ & $\begin{array}{c}\mathrm{R}^{\prime}, \\
(1 / \mathrm{Pa}) \\
\times 10^{-5}\end{array}$ \\
\hline 1 & 105 & 287 & 4.3 \\
2 & 102 & 289 & 4.7 \\
3 & 90 & 292 & 6.1 \\
4 & 140 & 224 & 1.9 \\
5 & 169 & 308 & 1.8 \\
6 & 161 & 309 & 2.0 \\
7 & 30 & 163 & 30.1 \\
8 & 129 & 229 & 2.3 \\
9 & 194 & 286 & 1.3 \\
\hline
\end{tabular}
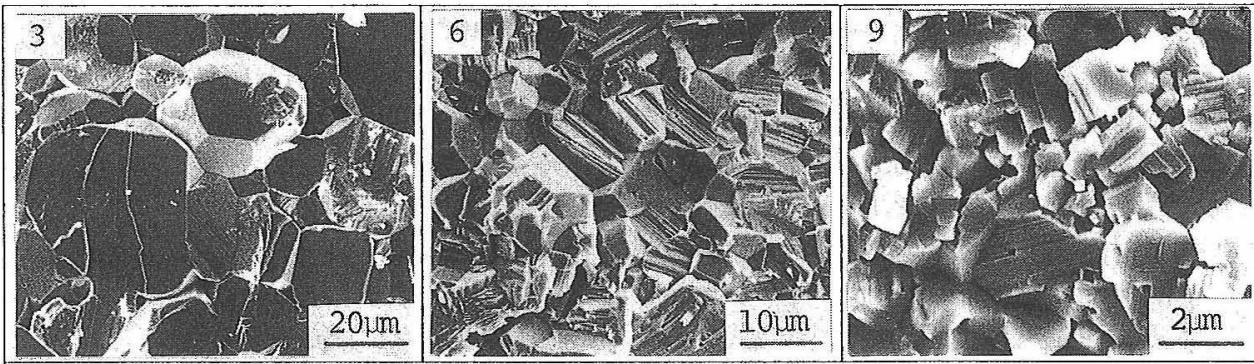

B e nd i n g Streng $\mathrm{t} h$
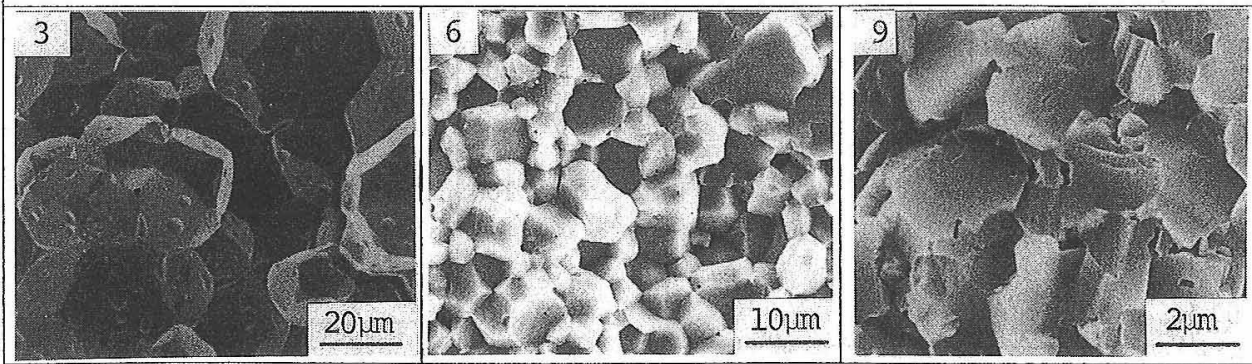

The rma 1 Shock

Da m a g e

Resistance

Fig. 4. Scanning electron micrographs of fracture surface for specimens of bending strength and thermal shock damage resistance. 
の試料は粒界破壊をしているが，粒子径が小さくなると ともに粒内破壊の割合が増し, NO. 9 の試料では大部分 が粒内破壊をしていることが分かる。このことは，粒子 径が大きいと熱応力による破壊と外部応力による破壊に 違いがあることを示している。すなわち，外部応力によ る破壊では亀裂が急速に進展するため, 粒内破壊を起こ すのに対して，粒子径が大きく熱応力で破壊する場合は 亀裂の進展がゆっくりした過程で進み粒界破壊を起こす と考えられる。

\section{文献}

1) 西田俊彦, 塩野剛司, 山内博之, 西川友三, 材料, 36, 17-21 (1987).

2）三上龍一, 伊熊泰郎, 小松和蔵, Gypsum \& Lime, 209,
219-24 (1987).

3) T. Vasilos, J. B. Mitchell and R. M. Spriggs, J. Am. Ceram. Soc., 47, 606-10 (1964).

4) S.C. Carniglia, J. Am. Ceram. Soc., 48, 580-83 (1965).

5) 西田明生, 島村常夫, 神徳泰彦, セラミックス論文誌, 97, 107-12 (1989).

6）浜野健也,「七ラミックスの機械的性質」, 窯業協会 (1979) pp. 36-37.

7) 中山 淳,「セラミックスの機械的性質」, 窯業協会 (1979) pp. 69-75.

8) R. W. Rice, S. W. Freiman and P. F. Becher, J. Am. Ceram. Soc, 64, 348-54 (1981).

9）塩野剛司, 野沢 浩, 西田俊彦, 西川友三, 昭和 63 年日 本セラミックス協会年会講演予稿集 (1988) p. 107.

10) R. M. Spriggs, L. A. Brissette and T. Vasilos, J. Am. Ceram. Soc., 45, 400 (1962).

11) 山本博孝,「セラミックスの強度と破壊対策」, 経営開発 センター出版部 (1984) p. 460. 